\title{
sciendo
}

CIVIL AND ENVIRONMENTAL ENGINEERING REPORTS

E-ISSN 2450-8594

CEER 2021; 31 (3): 0235-0250

DOI: $10.2478 /$ ceer-2021-0043

Original Research Article

\section{PROPOSAL FOR MODERNISATION OF LARGE BLOCK SYSTEM BUILDINGS (LBS) - FACADES - Lublin University of Technology}

\author{
Alina MIEDVIEDIEVA (WRIGHT) ${ }^{1}$, Anna OSTAŃSKA* \\ Politechnika Lubelska, Lublin, Poland
}

\begin{abstract}
The over 40-years-old housing stock from the industrialized mass housing era is today functionally deficient and does not meet the current needs of residents. In particular, there are numerous architectural barriers, the systems are worn and obsolete, and the number of housing types is very limited. Examples of the modernization of multi-story residential buildings (the article presents those from Russia and Ukraine) confirm that this problem is universal, and a significant improvement of the building's . utility value can be achieved through a relatively small modification of the building fabric: precast concrete structures of the buildings prove to be flexible enough to accommodate deep changes. The authors present a concept of modernization of a building erected in a "large block" system, typical for the Polish housing of the 1970s in many cities. The case study concerns a particular building located in Lublin in one of the large housing estates - the concept of its modernization is compatible with the local spatial development plan, the proposed solutions are architecturally coherent and technically feasible.
\end{abstract}

Keywords: precast concrete, housing, modernization, extension, façade

\footnotetext{
${ }^{1}$ Miedvediewa A., REBUILDING, EXPANSION AND SUPERSTRUCTURE OF THE RESIDENTIAL MULTI-FAMILY BUILDING KURANTOWA ST. 8 OF MONIUSZKI NEIGHBORHOOD IN LUBLIN. Praca dyplomowa pisana pod kierunkiem dr inż. Anny Ostańskiej, Katedra Architektury, Urbanistyki i Planowania Przestrzennego, kierunek Architektura, Wydział Budownictwa i Architektury, Politechnika Lubelska, Lublin 2018, *Corresponding author: Politechnika Lubelska, Wydział Budownictwa i Architektury, ul. Nadbystrzycka 40,20-618 Lublin, Poland, e-mail: a.ostanska@pollub.pl
} 


\section{INTRODUCTION}

In the second half of the 20th century, industrialized construction was at its bloom. Mass housing projects were executed throughout the Eastern Bloc countries, in particular in Poland, to answer housing needs of the post-war baby boom generations and changes in the economy. Newcomers to the freshly completed districts of expanding towns and cities, as well as settlements growing around factories, were both economic migrants from rural areas and people already established in the urban environment searching for decent living condition. The demand for flats was enormous, and the new estates were designed to quickly and economically provide affordable shelter for as many as possible without compromising the needs and expectations of modern societies.

The main target group of housing projects were young families, with the family models differing from these observed today. Back then, young people in their 20s and 30s shared living space with families of several people. Today, staying in the same flat, they often live alone. Their needs are naturally different from those anticipated by the architects. Their lower incomes (retirement) and poorer health add to the problem.

The results of recurrent surveys among the inhabitants of the aforementioned multifamily housing stock confirms the urgent need to retrofit buildings to reduce, or at least prevent the raise of the living costs. This appears to be possible through retrofitting aimed at improving energy performance of the buildings. It can be combined with changes to the buildings' envelope more radical than adding another layer of thermal insulation: replacing the existing (typically minute) balconies with larger and glazed ones to accommodate passive heat gains and provide auxiliary space for recreation - usable at any weather.

For the purpose of this article, the following definitions have been adopted:

- Modernization - a term absent in Polish Building Law, replaced by three notions: "overhaul", "vertical extension", and "horizontal extension" of a built facility. Here, the meaning of modernization is identical with functional upgrading the building accompanied by changes to the size and shape of the building and/or adding new components (e.g. systems).

- Overhaul is the effect of construction works that change the functional or technical performance of a building - except for its geometric parameters such as cubic capacity, footprint, height, length, width or the number of stories.

- Horizontal or vertical extension mean the effect of construction works that change the volume of the building by, correspondingly, changing total floor areas or the building's height or the number of stories. 
(LBS) - FACADES

\section{EXAMPLES OF MULTIFAMILY HOUSING MODERNIZATION IN EASTERN EUROPE}

The literature on the subject, as well as the authors' observations and building surveys in Poland and Ukraine, prompt that housing blocks erected in the nineteen-seventies, though structurally sound and still in demand, share multiple deficiencies: poor thermal insulation of the envelopes, bad acoustics of compartment walls and slabs, insufficiently lit circulation areas (though this is system-specific), limited choice of flat sizes and layouts, and obsolete wiring and plumbing. They also do not comply to modern standards of accessibility and even fire safety.

The problematic character of these generally valued and strikingly numerous assets as well as challenges of their maintenance and retrofit are observed by many architects and researchers. As the former Soviet Union used industrialized construction on impressive scale, many publications on the ways to deal with this heritage can be found in Russia and Ukraine (Dediukhina. and Petrenko [5], Buzyrev [4], Meerovich et al. [16], Oliinyk [20], Dmitriev [7], and Akuleva [1]). The topic seems less popular in Poland yet, and modernization proposals are not as bold as in Russia, but preventing deterioration of large-panel and large-block buildings is considered an issue (Ostanska [21, 22], Taczanowska and Ostańska [24], Obolewicz and Tomaszewicz [19]). The grim consequences of neglect in asset management was analyzed by Nowogońska and Mielczarek [18]. Many reports on retrofitting approaches to prefabricated housing stock can be found in western Europe (Droste and Lelevrier [8], Wassenberg [28], Turkington. and Van Kempen [25], Dekker [6]). The estate modernizations programs started in Germany in the early 21 st century were exemplary [26] and confirmed that building retrofits in a large scale are needed and feasible. Apart from economic, technical and organizational issues, the social aspects of housing stock redevelopment attracts researchers attention (among others, Alexander [2]).

A thorough analysis of the literature confirmed that the topic of the need for technical, functional and energy improvements in multifamily buildings is still relevant, as it has not yet been completed in many Eastern European countries. According to the authors, despite many modernization efforts, prefabricated buildings still need to continue to undertake the modernization process in order to meet the current technical conditions and the needs of the residents, as there is still an opportunity to reduce maintenance costs resulting from reduced thermal energy consumption.

\subsection{Russia}

The surveys on performance of Russian residential buildings conducted between 1990 and 2002 indicated that the number of failures grew over 2.5 times within 
this period [1]. This alarming news prompted two solutions: first to demolish the buildings and replace them with new ones, the other - a thorough modernization. Demolishing inhabited buildings or even whole estates seems difficult for social and organizational reasons (relocating people, managing the logistic process of removing and utilizing the debris), though rising prices of real estate and the possibility to increase the density of development provide economic justification for the idea (the "prefab" housing estates were planned lavishly in terms of land use). Sparing the buildings and modernizing them (including extensions and added stories) was estimated to be less costly (20-30\% cheaper than demolishing and building anew). Considering this, the Russian Academy of Architecture and Construction proposed an optimized construction method for residential buildings that merges energy upgrading with vertical extension of the existing low-rise housing. The overarching idea was to combine erection of new multi-story buildings and retrofitting the existing ones to improve living conditions and to extend the useful life of the old buildings, making them at least meet the current standards. This way, the total usable floor area can be doubled [3]. The effect of the proposed retrofit approach in Russia is:

- reduction in the cost of implementation by $12-15 \%$ compared to a new building; reduction in operating costs by $30-40 \%$ due to reduced energy consumption;

- more economical land use $15-20 \%$, due to increased density of development;

- broadening the offer of dwelling types (from 1- to 6-room apartments, 2storey apartments), adding space for technical rooms;

- use of basement for parking spaces; solving accessibility issues, adding extra space - winter gardens;

- introduction of an "active first floor" for social integration, with recreational (gym), commercial (small retail establishments, hairdresser) and social (library) functions; change of the building shape and improved façade.

In St. Petersburg, the "Regional program of reconstruction of residential buildings of the first mass series" was implemented in 2000 to modernize 6.3 million $\mathrm{m}^{2}$ of dwellings in large panel buildings and 2.6 million $\mathrm{m}^{2}$ of flats located in brick buildings [23]. The program is still in progress, but the measures taken so far resulted in:

- increasing of the usable floor area of dwellings by $1000 \mathrm{~m}^{2}$;

- reclamation of 0.15 ha of brownfield area;

- 1.5 times reduction of heat losses compared to new housing;

- modernizing the estates' infrastructure at a cost 1.5 times lower than the cost of providing new infrastructure in new estates.

The Moscow project to modernize five-story housing blocks series 1- 515/MI started in 2002, and drawing from St. Petersburg experience [15]. A part of it 
involved three identical prefabricated blocks at 4-6-8 Khimkinskiy Bul'var in Severnoye Tushino District, the middle building no. 6 was demolished and replaced with a new 22 -story housing tower and a 3 -story underground parking. Buildings 4 and 8 were equipped with four additional stories and thoroughly modernized (Figures 1-4).

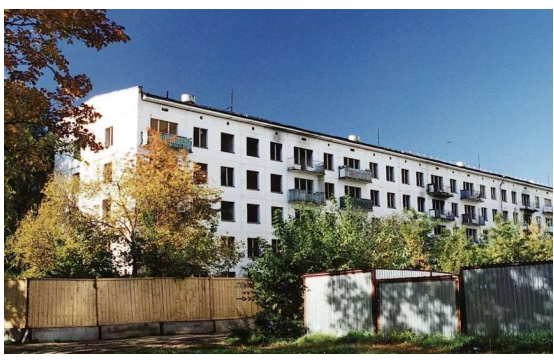

Fig. 1. Moscow, 2002. Building at 8 Khimkinskiy Bul'var before modernization [15]

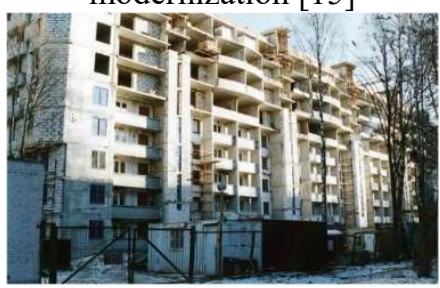

Fig. 3. Moscow, 2002. Building at 4 Khimkinskiy Bul'var - vertical extension in progress [15]

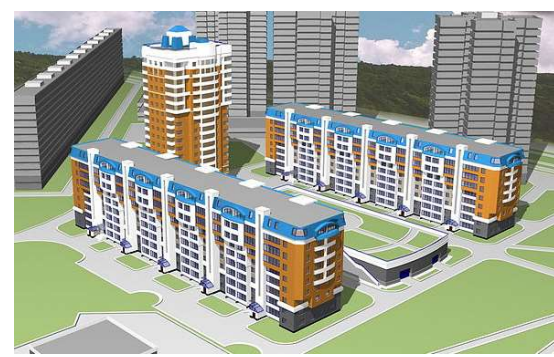

Fig. 2. Moscow, 2002. Visualization of 4-6-8 Khimkinskiy Bul'var modernization [15]

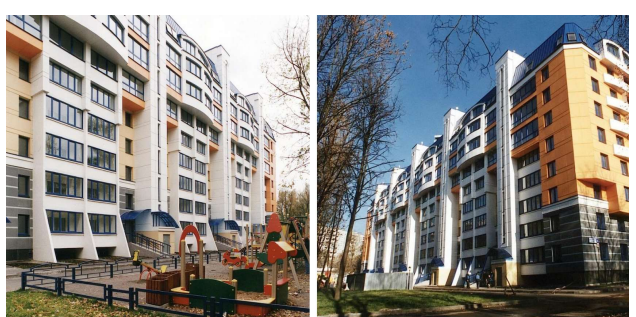

Fig. 4. Building at 8 Khimkinskiy Bul'var after modernization [15]

Another Moscow housing unit subject to thorough changes was 14 Marshal Rybalko Street (Figure 5): extended vertically and horizontally and accompanied by a new tower block. 

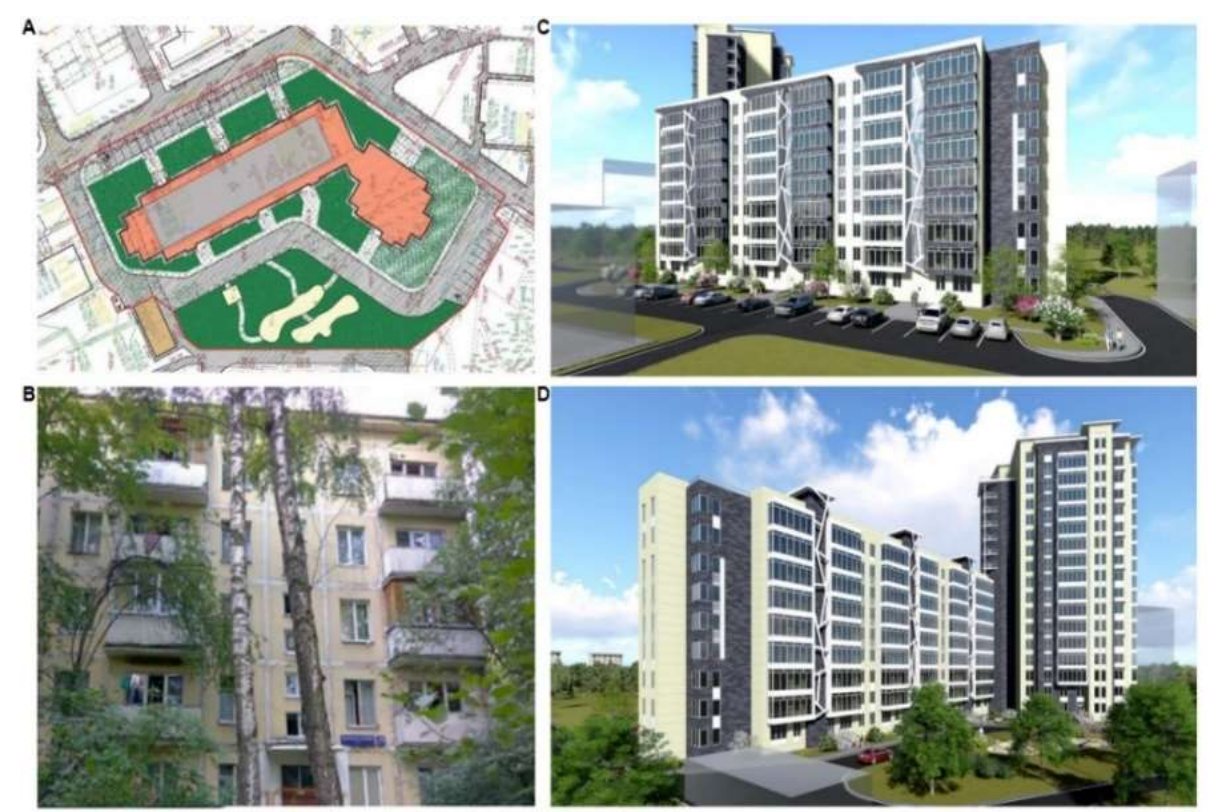

Fig. 5. Project at 14 Marshal Rybalko Street, Moscow. A - site development plan, B south façade after modernization, $\mathrm{C}$ - original façade, D - north façade and new tower block. Source: B, A, C, D [15]

The above Russian examples confirm that modernization helps solving problems of obsolescence of residential buildings together with the problem of scarcity of land for new development: from the improvement of the standard of flats and the estate's infrastructure, adding to aesthetic qualities of the neighborhood, to making better use of urban space, especially in large and expanding cities.

\subsection{Ukraine}

The most common types of 40-years-old large panel housing blocks Series KT, BPS, and 96-134 (Figure 6) show significant evidence of wear and tear and obsolescence. The special legal act "On complex reconstruction of quarters (neighborhoods) of the dilapidated housing stock" requires that modernization (in fact, urban renewal) must involve whole neighborhoods - they need to be brought to compliance with Ukrainian Building Code [9]. 

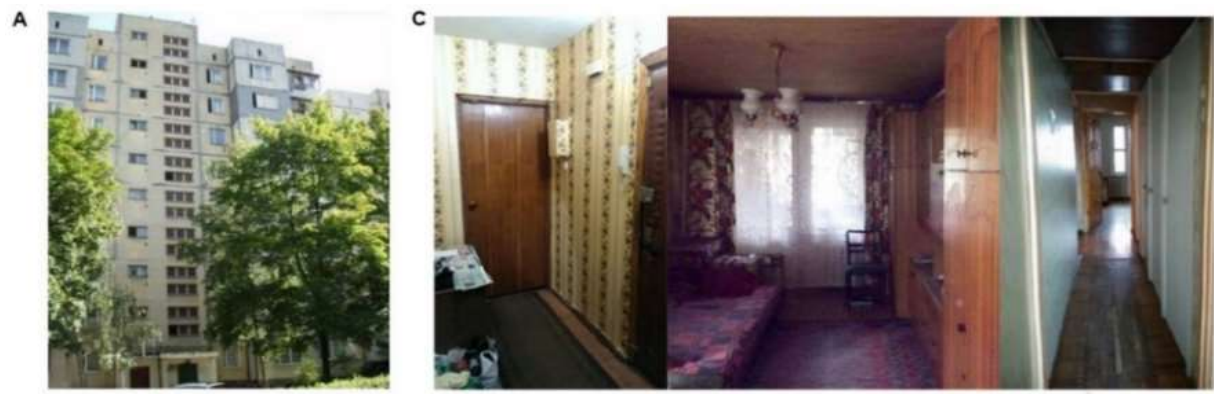

B lokalizacja: ul. A. Bojczenko 6, Kijów, Ukraina seria: $111-96 \mathrm{XX}$

czas budowy: 1980 rok

materiał ścian nośnych: płyta żelbetowa

strop: plyta żelbetowa

dach: stropodach $\mathrm{z}$ poddaszem

ilość kondygnację: 9

wysokość kondygnacji: 2,7-2,75

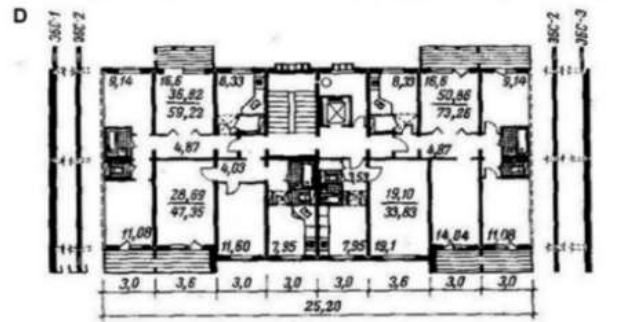

Fig. 6. Kiev, housing block Series 96: A - south façade (current state); B - basic data, C - typical flat; D - typical floor plan. Source: A,B [9]; C [14]; D [13].

The city of Ivano-Frankivsk implemented a project to improve housing energy performance. The city offers financial support for technical measures such as thermal insulation of facades, replacing windows, repairing roofs and basements and replacing lighting systems [10].

\section{CASE STUDY - MODERNIZATION PROPOSAL}

The case study on modernization of a "typical" housing block was based on proposals presented in the master thesis by Miedviedieva [17] supplemented by conclusions from the direct inspection of the building and a survey among the residents concerning, among others, opinions on modifications to the building's fabric. The proposals selected for presentation in this paper focus on changes in the façades (including change to the size of glazed areas) and balconies.

\subsection{The object of analysis}

The object of analysis is an existing building that belongs to a housing cooperative's estate Moniuszki in Lublin, Poland. The building is a typical 11storey structure of a large block system (hollow core slabs and load bearing walls of the superstructure, non-bearing external walls of integrated aerated concrete 
elements, in-situ reinforced concrete foundations and basement walls, ventilated flat roof). The basic parameters of the building are as follows:

- usable area of the apartments $-4.527,0 \mathrm{~m}^{2}$;

- number of apartments - 88;

- building volume $-21.254,0 \mathrm{~m}^{3}$;

- building footprint area $-614,4 \mathrm{~m}^{2}$;

- number of stories - 11 plus basement;

- height of the building - approximately $36 \mathrm{~m}$.

As the thermal insulation of the building proved inadequate, the envelope was subject to several stages of partial insulation. An on-site survey conducted in 2020 confirmed a generally good condition of the building.

\subsection{Problem definition and scope of analysis}

To recognize functional deficiencies of the estate and buildings, an in-depth direct interview was conducted among the residents. The survey was repeated twice in 5-year intervals, so in 2004 and 2009 [21, 22]. The surveys provided up-to-date input on the perceived needs of the inhabitants. According to the residents, the key problems included the following:

- too small flat and balcony sizes;

- limited number of dwelling types;

- accessibility problems (narrow doorways, entrance to the building accessible only by a steep flight of stairs)

- lack of common areas - no chance of neighborly interaction;

- obsolete systems (however, these are not considered in this analysis).

The proposals of modifications to the building fabric focus on changes in building elevations (shape of windows and balcony doors, replacing and glazing balconies). Functional changes will be described in another paper.

\subsection{Summary of modifications}

The layout of the building consists of two rectangular segments, connected by a circulation area (two elevators and a separate staircase) has been redesigned. The extension consists in expanding the first floor of the building on its southern and northern sides by approx. 1,94 $\mathrm{m}$ in order to enlarge the multifunctional space, which was built up with glazing units. Above, the shape of windows and balcony doors was changed, and the existing balconies removed to be replaced with larger, arranged in a different pattern and glazed. Due to structural design of the façade, non-bearing outer walls can be easily removed - this opportunity was used to replace them with three-part sliding doors providing access to the terrace. The proposed vertical extension consists in adding one story, but leaving a part of the former roof to serve as a terrace. The roof over the new story is flat with a slope 
of $2^{\circ}$. On the western and eastern side, a full-height glass cladding constitutes a unified whole with the newly designed glazed extension of the first floor together with the transformation of the entrance zone. A glazed external staircase was also designed to connect the first floor with the street level. A ramp and an extra entrance to the building is added to improve the building's accessibility. The building was originally equipped with garbage chutes leading to a garbage room with containers - as current waste management practices as well as approach to hygiene made them obsolete, they are to be removed and the space used to install an elevator - spacious, accessible and serving all floors from the ground level to the top of the building. The footprint area as well as the shape of the building changes due to the extension and thermal insulation, as shown in Table 1.

Table 1. Main building parameters before and after modernization [17]

\begin{tabular}{|l|r|r|r|}
\hline Parameter & Before [19] & After & Comment \\
\hline Width & $21,42 \mathrm{~m}$ & $25,26 \mathrm{~m}$ & Increased by over $4 \mathrm{~m}$ \\
\hline Length & $43,50 \mathrm{~m}$ & $43,90 \mathrm{~m}$ & Increased due to adding insulation \\
\hline Height & $34,20 \mathrm{~m}$ & $35,90 \mathrm{~m}$ & Increased by about $2 \mathrm{~m}$ \\
\hline
\end{tabular}

\section{EXPLANATION OF THE DESIGN}

\subsection{Composition and function}

The design idea was based on securing the necessary thermal conditions in the building to reduce thermal energy consumption and improve the comfort of building use. In its original form, the building has only residential function. The proposal introduces more function into the first floor, thus $85 \%$ of the residential function and $15 \%$ of the service function was obtained.

The design of the body of the building was aimed to create a sense of transparency around the edges of the building, or integration between nature and architecture. This was achieved through the use of glazed surfaces in gable walls to reflect sky and surrounding trees. In order to improve the feeling of penetration of natural space into architectural space, the original small balconies were replaced with bigger, more functional structures. The first floor was expanded, enclosed by glazing and covered with a green roof. Figures 8 and 9 present the evaluation of the idea of space integration concept. 

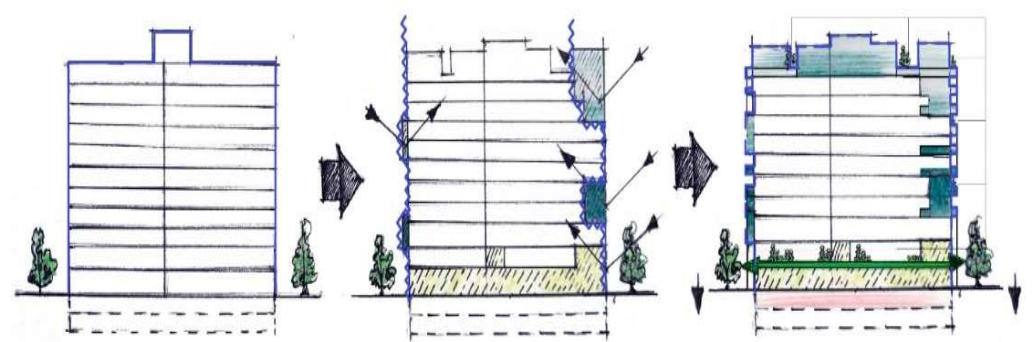

Fig. 8. Concept evaluation scheme of the modernization project of a block of multifamily residential building in Lublin [17]

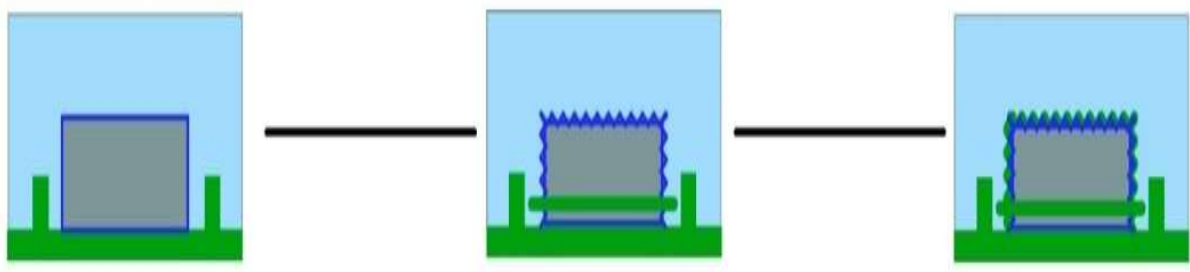

Fig. 9. Schematic of the concept of "softening" the border between the building and the environment [17]

The organic character of the building is further emphasized by the decorative laths used on the façades that imitate the branches of a tree and emphasize the vertical spatial arrangement of the building. From a functional point of view, they are transparent screens that separate the balcony in order to give a feeling of privacy to the residents and to mask the installed outdoor air conditioning units inside. On the façade, analogous laths were designed to control insolation and the installation of photovoltaic panels.

The original composition of the façade is symmetrical. The ratio of the façade length to height is 1 to 2 . The design also includes a new arrangement of windows and balcony doors with different dimensions than the original ones, which have been combined into repetitive modules on the façade (Fig. 10). Thus, 8 modules were designed, 6 - for the right segment and 4 - for the left segment. 2 repetitive rows were designed for each side. Each row contains equal number and arrangement of repetitive modules, i.e. 3 - repetitive modules in the right side rows and 2 - in the left side rows (Figure 10). 

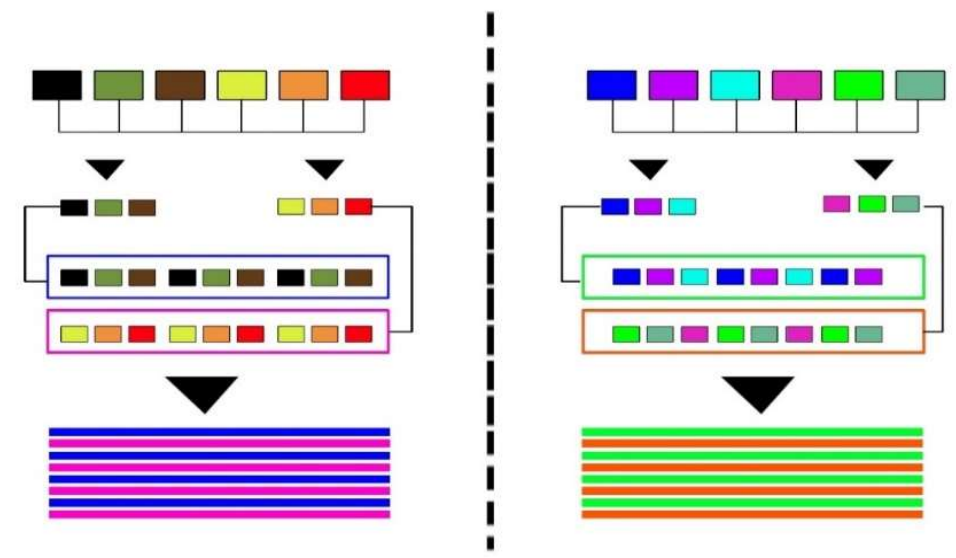

Fig. 10. Schematic diagram of the façade module combinations for the modernization project of a multi-family residential building in Lublin [17]

\subsection{Structural considerations}

The load-bearing structure and curtain walls remained unchanged, apart from a few replacements in the envelope in the upper part of the building as well as removing curtain walls in the first floor to enable extension.

\subsection{Changes to facade}

New repeating façade modules were designed in accordance with the original façade panel layout. By 2020, the building has been partly insulated three times (Fig.11).
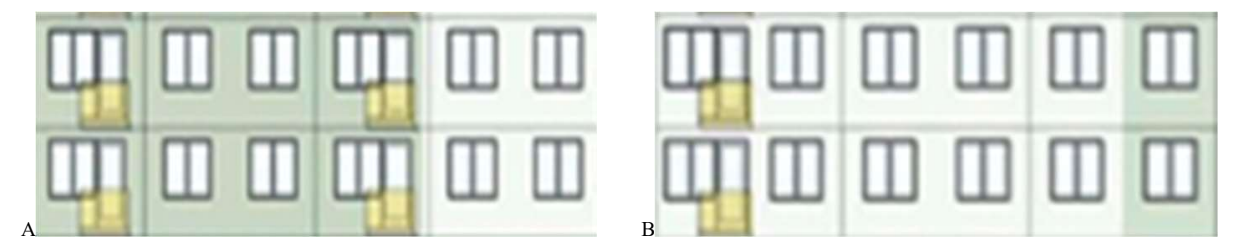

Fig. 11. Original layout of windows,

building after the 3rd stage of insulation [17] - as in 2020 .

A - left segment, B - right segment

To adjust the façade to changes in the layout of the interior, the curtain wall panels made of integrated aerated concrete segments need to be modified. The design provides for additional reinforcement of the lintels (using e.g. Helifix system [12]) and changing shape of openings as in (Figures 12). 


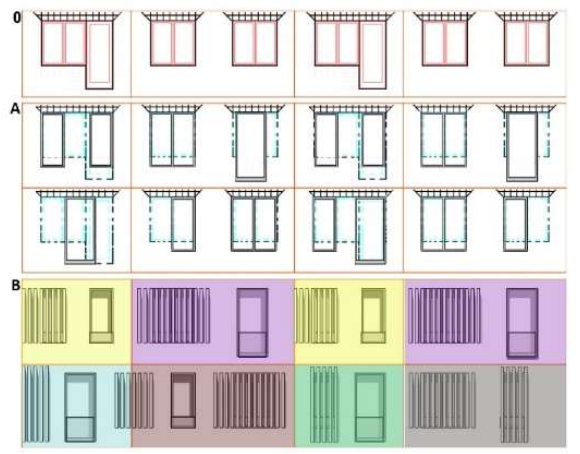

Fig. 12. Schematic of the location of the modules on the left side of the elevation [17] 0 - additional reinforcement of lintels with Helifix [12]; A - changes to the shape of openings; B - proposed pattern of façade modules on the example of two storeys with vertical covers made of lamellas

The vertical communication axis of the building (stairs and corridors) was emphasized by vertical glazing over the entire height of the building (Figure 13). A modern accent is the extension of the first floor and new big but light-structure balconies (e.g. Alucomposites [11]), which were additionally enclosed by glazing. The openings and balconies were added also on originally blank gable walls.

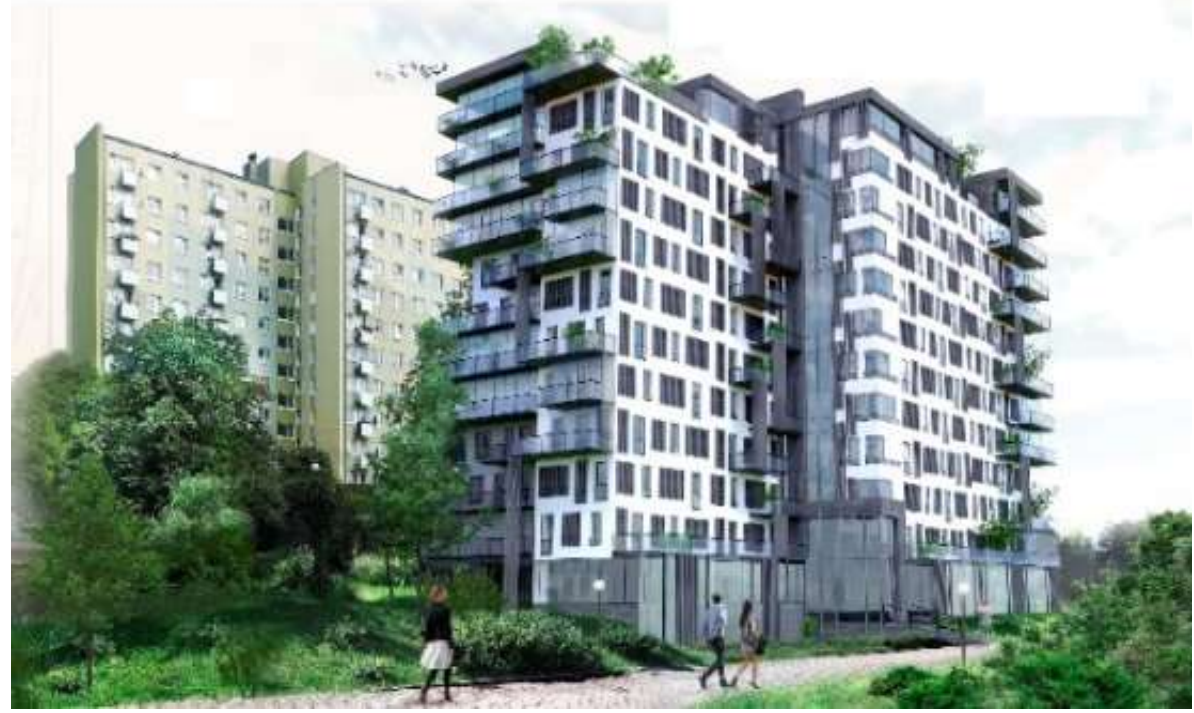

Fig. 13. Visualization of changes - unmodified neighboring building in the background [17] 
(LBS) - FACADES

\subsection{Discussion}

The housing estate management maintains the buildings and infrastructure of the analyzed estate with care. They undertook several attempts to reduce energy consumption of the buildings by insulating the envelope. First, only the windowless side walls were insulated with mineral wool on lattice covered by metal sheets. The same method was applied to the remaining walls of all buildings in the estate between 2004 and 2014. The cladding was then stripped and replaced with ETICS; all buildings in the estate were insulated in 2018-2021. No functional and aesthetic improvements were made: all works preserved the original shape of two simple cuboids connected by a stairwell. Therefore, the proposed set of solutions, though cost-intensive and generating disturbance for the users for the time of construction works, introduces a serious change in terms of aesthetics and function (Figure 13). The effect was achieved by using contrasting colors on the facade, glazing, replacing window and door frames together with replacing balconies with larger ones, and using vertical panels on the facade. Functional changes (the scope described in the paper, excluding changes to the flats analyzed separately) improve usability of the building: they provide better natural lighting and possibility to use both passive heat gains and solar power (installation of PV panels), actually useful balcony space (increased size, protection from the elements by glazing), accessible roof, accessible circulation facilities, and introduce new functions to the originally only residential building.

\section{CONCLUSIONS}

The need to modernize multi-family residential buildings was confirmed by detailed architectural analyses taking into account the structural possibilities. They provided input for conceptual proposal of solutions to be applied to a particular building located at Kurantowa 8 Street in Moniuszko Housing Estate in Lublin. The work is a pioneer example, on the national scale, of possibilities to thoroughly modify the "prefab buildings". From the structural point, the modifications involve removing elements of the original envelope and making necessary reinforcements using a non-invasive reinforcement system. Moreover, the works can be performed while the building is in use, which lessens the logistic burden of the project.

The new envelope gives an original look to the building and helps meet current energy conservation requirements. The new balconies, bigger and glazed, are lightweight steel frame filled with composite panels. Decorative lamellas protect the façade from summer overheating, so that the apartments are still bright, and as a result the building is energy efficient. 
This paper, is only the beginning of solutions to improve the quality of life in prefabricated buildings.

The paper shows that the concept proposed for the analyzed tall residential building is technically feasible, although it undoubtedly requires multidisciplinary cooperation of specialists and the project stakeholders.

\section{REFERENCES}

1. Akulenkova, IV 2004. Efficiency of Reconstruction of Residential Buildings (on the Example of St. Petersburg). diss. Cand. of Economics: 08.00.05. Saint Petersburg State University of Architecture and Civil Engineering. Saint Petersburg.

2. Alexander, C 2008. Język wzorców. Gdańskie Wydawnictwo Psychologiczne. Gdańsk. s. 1209.

3. Bulgakow, SN 1998. Nowe problem i metody rozwoju nowych miast Prom i cywilne bud. -. № 3. c. 11-12.

4. Buzyriev, VV. Модернизация жилищного строительства в среднесрочной перспективе: проблемы и решения. Строительный комплекс: экономика, управление, инвестиции: Межвуз. сб. науч. тр. Вып.11. - СПб.: Изд-во СПбГУЭУ, 2011. - С. 4-12.

5. Dediukhina, ES and Petrenko, MA 2014. Foreign experience of capital reconstruction of block of flats with the use of innovative ways. Известия вузов. Инвестиции. Строительство. Недвижимость № 5 (10) Иркутск Россия.

6. Dekker, K, Hall, S, van Kempen R and Tosics, I 2005. Restructuring large housing estates in European cities: an introduction. Chapter 1, pp. 1-17. The Policy Press, University of Bristol, Great Britain.

7. Dmitriew, AP and Yakubowicz, GN 1998. Rekonstrukcja pięciopiętrowej masowej zabudowy mieszkaniowej i ekonomiczne metody jej prowadzenia. Przemystowe i cywilne budownictwo 8, 29-31.

8. Droste, $\mathrm{C}$ and Lelevrier, C. Urban regeneration in European social housing areas. UrbanPlus Droste \& Partner, Berlin, Urban Planning Institute, University of Paris.

9. http://kga.gov.ua/rss/120-shcho-peredbachae-rekonstruktsiya-khrushchovok. Dostęp 2018.

10. http://styknews.info/novyny/komunalka/2017/12/11/frankivs-k-povertaty80-za-uteplennya-budy-nkiv-ta-50-za-remont-pidyizdiv. Dostęp 2018.

11. http://www.alucomposites.pl/. Dostępność 2021.

12. http://www.helifix.pl/. Dostęp 2021.

13. http://www.kvmeter.ru/information/homes_series/111_96/. Dostęp 2018. 
14. https://dom.ria.com/ru/realty-prodaja-kvartira-kiev-dneprovskiy-aleksandraboychenko-ulitsa-14277395.html. Dostep 2018.

15. https://www.akrotov.ru/blank-5. Dostęp 2018.

16. Meerovich, MG, Malko, AV, Kozlova, LV and Gladkovainnych, EA 2017. Реновация панельной застройки 1960-1980-х гг. в Германии. Известия вузов. Инвестиции. Строительство. Недвижимость. Т. 7. № 1. С. 111119.

17. Miedvediewa, A 2018. Rebuilding, expansion and superstructure of the residential multi-family building Kurantowa st. 8 of Moniuszki neighborhood in Lublin. Praca dyplomowa pisana pod kierunkiem dr inż. Anny Ostańskiej, Katedra Architektury, Urbanistyki i Planowania Przestrzennego, kierunek Architektura, Wydział Budownictwa i Architektury, Politechnika Lubelska, Lublin, maszynopis, s. 57.

18. Nowogońska, B and Mielczarek, M 2021. Renovation Management Method in Neglected Buildings, Sustainability, January DOI: 10.3390/su13020929.

19. Obolewicz, J and Tomaszewicz, D 2016. Problemy modernizacji budynków wielkopłytowych osiedli mieszkaniowych. Centrum Rzeczoznawstwa Budowlanego Sp. z o.o. Nr. 1. Białystok, Polska.

20. Oliinyk, NI 2015. Foreign experience in the sphere of reconstruction of housing building National Academy of Public Administration at Presidential Ukraine, Kyiv, Ukraine.

21. Ostańska, A 2009. Podstawy metodologii tworzenia programów rewitalizacji dużych osiedli mieszkaniowych wzniesionych w technologii uprzemysłowionej

na przykładzie osiedla im. St. Moniuszki w Lublinie. Politechnika Lubelska, Monografie Wydziału Inżynierii Budowlanej i Sanitarnej Vol. 1, Wydawnictwa Uczelniane Lublin, 1-173.

22. Ostańska, A 2018. Programowanie rewitalizacji osiedli mieszkaniowych z zastosowaniem modelu PEARS. Lublin: Polska Akademia Nauk, 169 s. ISBN 978-83-939534-4-8.

23. Owczynnikowa, NP. 2001. Zabudowa mieszkalna Sankt- Petersburgu. Budownictwo cywilne 4, 58-61.

24. Taczanowska, T and Ostańska, A 2012. Dokładność realizacji a potrzeba modernizacji budynków wielkopłytowych. Dom Wydawniczy MEDIUM. Warszawa.

25. Turkington, R, van Kempen, R and Wassenberg, F 2004. High-rise housing in Europe. Current trends and future prospects. DUP Science. Housing and Urban Policy Studies are edited by OTB Research Institute for Housing, Urban and Mobility Studies. Delft University of Technology Copyright by Onderzoeksinstituut OTB, 2628 BX Delft, The Netherlands. 
26. Urban, F 2011. Mass Housing in East and West Germany - Controversial Success and Ambivalent Heritage. Mass Housing, Edinburgh, Edinburgh College of Art.

27. Ustawa Prawo budowlane (1994), Dz.U. 2020 poz. 471. Ustawa z dnia 13 lutego 2021 o zmianie ustawy - Prawo budowlane oraz niektórych innych ustaw. D20200471Lj.pdf. Accessed 2021.

28. Wassenberg, F. OTB Research Institute, Delft University of Technology. Social Housing in Europe Chapter 11. LSE, London School of Economics.

Editor received the manuscript: 26.04.2021 